Anselmetti, F.S., Isern, A.R., Blum, P., and Betzler, C. (Eds.)

Proceedings of the Ocean Drilling Program, Scientific Results Volume 194

\section{ORIGIN AND Age Of SUbMarine FERROMANGANESE HARDGROUNDS from the Marion Plateau, OFFSHORE NORTHEAST AUSTRALIA'}

\author{
P.R. Heck, ${ }^{2,3,4}$ M. Frank,, ${ }^{3,5}$ F.S. Anselmetti, ${ }^{4}$ and P.W. Kubik ${ }^{6}$
}

${ }^{1}$ Heck, P.R., Frank, M., Anselmetti, F.S., and Kubik, P.W., 2007. Origin and age of submarine ferromanganese hardgrounds from the Marion Plateau, offshore northeast Australia. In Anselmetti, F.S., Isern, A.R., Blum, P., and Betzler, C. (Eds.), 2006, Proc. ODP, Sci. Results, 194: College Station, TX (Ocean Drilling Program), 1-22. doi:10.2973/odp.proc.sr.194.008.2007

2Max-Planck-Institute for Chemistry, Particle Chemistry Department, Becherweg 27, D-55128 Mainz, Germany. heck@mpchmainz.mpg.de

${ }^{3}$ Institute for Isotope Geology and Mineral Resources, NW C84, ETH Zurich, CH-8092 Zurich, Switzerland. ${ }^{4}$ Geological Institute, ETH Zurich, $\mathrm{CH}$ 8092 Zurich, Switzerland.

${ }^{5}$ IFM-GEOMAR, Leibniz Institute for Marine Sciences, University of Kiel, Wischhofstrasse 1-3, 24184 Kiel, Germany.

${ }^{6}$ Paul Scherrer Institute, c/o Institute for Particle Physics, ETH Zurich, CH8093 Zurich, Switzerland.

Initial receipt: 9 March 2004 Acceptance: 20 October 2006

Web publication: 30 March 2007 


\section{INTRODUCTION}

Drilling during Ocean Drilling Program (ODP) Leg 194 on the Marion Plateau offshore the Great Barrier Reef in northeast Australia documented the depositional history of a carbonate-dominated shelf (Isern, Anselmetti, Blum, et al., 2002). Sedimentation on this subsiding basement started after rifting in the Cretaceous and a transgression during the Oligocene-early Miocene. Two major carbonate platforms were established, the Northern and Southern Marion Platforms (NMP and SMP, respectively), which grew to the middle and late Miocene, respectively, after which both edifices drowned (Isern, Anselmetti, Blum, et al., 2002). The NMP became buried after drowning under a thin veneer of deeper water deposits; the SMP today still stands out topographically with moderate relief above the surrounding seafloor.

Today, the shelf lies in a water depth between 300 and $500 \mathrm{~m}$ (Fig. F1). The sedimentation pattern is strongly influenced by ocean currents that have been responsible for local and periodic winnowing, causing condensed or absent sediments in some areas and focusing of the sedimentation in others. Leg 194 drilling revealed a series of unconformities characterized by the presence of submarine hardgrounds at many of the sites, indicating major hiatuses in the sedimentary record. These surfaces can also be identified on seismic data (Fig. F2) and in sediment petrographic, biostratigraphic, and petrophysical data (logging data) (Isern, Anselmetti, Blum, et al., 2002; Isern et al., 2004). Using seismic stratigraphy as well as biostratigraphy, these unconformities and associated hiatuses were dated and put into an overall depositional/stratigraphic context (Isern, Anselmetti, Blum, et al., 2002). New isotope geochemical analyses of the hardgrounds that represent the hiatuses and mainly consist of ferromanganese encrustations are presented in this study with the goal of validating and refining the stratigraphic interpretations and ages and understanding the genesis and growth rates of the ferromanganese crusts. Deep-sea hydrogenetic ferromanganese crusts represent condensed chemical sedimentary sections, which reflect the radiogenic and Be isotope composition of ambient deep water. The evolution of the radiogenic isotope composition at particular locations over time has been used successfully to reconstruct changes in deep ocean circulation and weathering inputs over as long as the past 60 m.y. (see Frank, 2002, for a review). Geochemical data from ferromanganese nodules grown in shallow water have been used to reconstruct environmental changes (Hlawatsch et al., 2002).

\section{SAMPLES}

For this work, two submarine hardground crusts from the Marion Plateau were investigated (Table T1): one from the modern seafloor covering the top of the SMP (Site 1196) at $300 \mathrm{~m}$ water depth and one from $117 \mathrm{~m}$ subsurface depth (Site 1194) marking the top of a lowstand platform positioned on the upper slope of the NMP (Isern, Anselmetti, Blum, et al., 2002).
F1. Queensland and Marion Plateaus, p. 9.

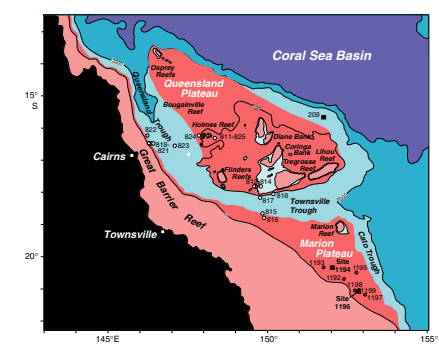

F2. Seismic profile through the SMP, p. 10.

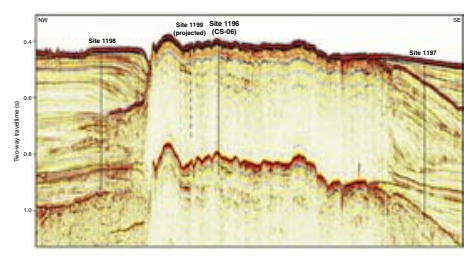

T1. Sample locations, p. 20. 


\section{Submarine Hardground on top of the Southern Marion Platform (Site 1196)}

During the site survey cruise, large pieces of the surface crusts of 1-3 $\mathrm{cm}$ thickness were recovered by dredging (Samples 1196-DR-02 and 1196-DR-04). The dredged crusts are reddish and are extensively colonized by serpulids, bryozoans, and solitary corals (Fig. F3). Leg 194 drilling on the SMP yielded another example of such a surface crust at Site 1196, which was recovered at the top of Core 194-1196B-1R.

Thin sections of the crusts show stromatholithic reddish brown laminae (growth banding?) encrusting a biomicritic carbonate containing abundant planktonic foraminifers, less abundant bryozoans, mollusk shells, and solitary corals. Most likely, biofilms started to grow on the rigid carbonate framework of the drowned platform, which precipitated iron and manganese from seawater. As can be seen in thin section, ferromanganese laminae grew on the exposed surfaces of seafloor rocks and in small cavities and cracks (Fig. F4). In some sections laminations show abrupt changes of color and composition along fine fractures while conserving the laminated texture.

\section{Submarine Hardground in the Subsurface on the Upper Slope of the Northern Marion Platform (Site 1194)}

Site 1194 was drilled through the lowstand NMP and recovered a hardground consisting of ferromanganese crust at 117.4 meters below seafloor coinciding with a seismic unconformity. This crust is also characterized by a very prominent natural gamma ray peak in the downhole logging data. Section 194-1194A-14X-1 contains this 1-mm-thick hardground crust that infilled an almost vertical crevass (Fig. F5).

\section{METHODS}

Hardground crusts were cut with a rock saw to obtain thick slides and thin sections. Iron and $\mathrm{Mn}$ elemental maps were obtained using an electron microprobe, and ${ }^{9} \mathrm{Be}, \mathrm{Nd}, \mathrm{Co}, \mathrm{Ni}, \mathrm{Mn}, \mathrm{Fe}$, and $\mathrm{Cu}$ concentrations were measured by inductively coupled plasma-mass spectrometry (ICP-MS) at the Institute for Inorganic Chemistry of ETH (Switzerland). ${ }^{10} \mathrm{Be}$ concentrations were measured at the accelerator mass spectrometry (AMS) facility of the Paul Scherrer Institute and the Institute for Particle Physics of ETH following standard procedures. Chemical preparation of samples for the ${ }^{10} \mathrm{Be}$ AMS measurements closely followed a previously described method (Henken-Mellies et al., 1990). ${ }^{10} \mathrm{Be}$ concentrations were normalized to internal standard S555 with a nominal ${ }^{10} \mathrm{Be} /{ }^{9} \mathrm{Be}$ ratio of $95.5 \times 10^{-12}$. Age calculations were carried out by applying a ${ }^{10} \mathrm{Be}$ radioactive half-life of $1.5 \mathrm{~m} . \mathrm{y}$. Nd isotope compositions were determined using a Nu Plasma multicollector ICP-MS following the chemical separation procedure of Cohen et al. (1988). ${ }^{143} \mathrm{Nd} /{ }^{144} \mathrm{Nd}$ was normalized to ${ }^{146} \mathrm{Nd} /{ }^{144} \mathrm{Nd}=0.7219$ to correct for instrumental mass bias. Agecorrected $\varepsilon_{\mathrm{Nd}(\mathrm{T})}$ values were calculated using ${ }^{147} \mathrm{Sm} /{ }^{144} \mathrm{Nd}=0.115$. The errors shown on the figures are $2 \sigma$ external reproducibilities based on repeated measurements of the JMC-Nd standard. The $2 \sigma$ external precision for the $\mathrm{Nd}$ isotope measurements of different sessions varied between 18 and $41 \mathrm{ppm}$. All ratios presented are normalized to given
F3. Dredged ferromanganese crust, p. 11.

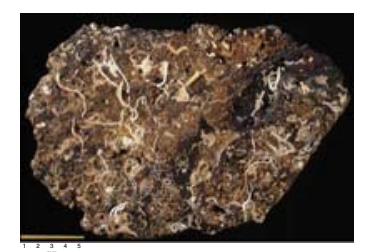

F4. Thin section from surface hardground, p. 12.

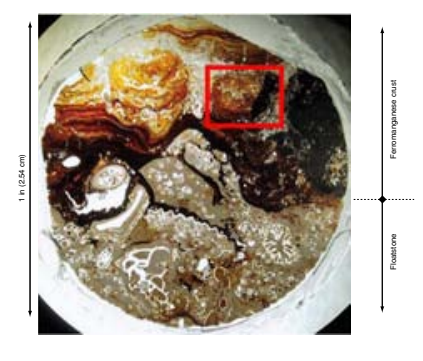

F5. Location of subsurface crust in NGR log, p. 13.

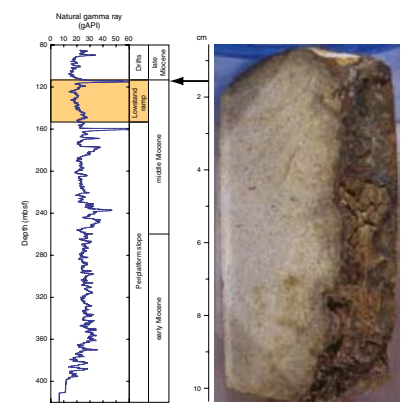


standard values: for JMC-Nd a given ${ }^{143} \mathrm{Nd} /{ }^{144} \mathrm{Nd}$ ratio of 0.511833 cross-calibrated to the La Jolla standard (0.511858) was used. Run precision for each sample was better than the external reproducibility. $\mathrm{Nd}$ isotope ratios are expressed as $\varepsilon_{\mathrm{Nd}}$ values, which denote the deviation of the measured ${ }^{143} \mathrm{Nd} /{ }^{144} \mathrm{Nd}$ ratio from the chondritic uniform reservoir CHUR (0.512638) multiplied by 10,000.

\section{RESULTS AND DISCUSSION}

\section{Be Isotopes}

Two profiles for Be isotope analyses with a resolution of $2 \mathrm{~mm} / \mathrm{sam}$ ple were sampled across the Fe-rich and the Mn-rich laminae of the seafloor-surface crust in Core 194-1196B-1R. In addition, Be isotopes were measured on two other recent hardground samples and on the deep subsurface hardground crust (Table T2). Unlike many other studies on hydrogenetic ferromanganese crusts (cf. Frank, 2002, and references therein), no downward decrease of the ${ }^{10} \mathrm{Be}$ concentrations is observed (Fig. F6). This is also not the case after normalizing to stable ${ }^{9} \mathrm{Be}$ to account for possible dilution effects. The ${ }^{10} \mathrm{Be} /{ }^{9} \mathrm{Be}$ ratios vary between $1 \times$ $10^{-7}$ and $1.5 \times 10^{-7}$ with an average of $1.16 \times 10^{-7}$, which is within errors identical to the range of recent growth surfaces of hydrogenetic Pacific deepwater ferromanganese crusts (von Blanckenburg et al., 1996). Similar ratios have also been obtained for the two other surface hardground crusts. This clearly documents that the hardground crusts are hydrogenetic precipitates that have incorporated the isotopic composition along ambient deep waters during growth. The range and the similarity of the ${ }^{10} \mathrm{Be} /{ }^{9} \mathrm{Be}$ ratios to other present-day surface values of deep-sea ferromanganese crusts also limits the growth period to within the past few 100 k.y. Growth rates must therefore have been significantly higher than those of deep-sea hydrogenetic ferromanganese crusts (0.5-15 $\mathrm{mm} / \mathrm{m} . \mathrm{y}$.). We would like to point out that there is the possibility that the crusts had an initial ${ }^{10} \mathrm{Be} /{ }^{9} \mathrm{Be}$ ratio of up to $2.5 \times 10^{-7}$, similar to water column measurements from $\sim 300 \mathrm{~m}$ water depth at other locations in the Pacific Ocean (Kusakabe et al., 1987). The crusts would accordingly have stopped growing for the past $\sim 2$ m.y.; however, we consider this very unlikely in view of the favorable conditions for the growth of ferromanganese crusts on the SMP.

In view of the narrowly constrained present-day initial ${ }^{10} \mathrm{Be} /{ }^{9} \mathrm{Be}$ ratio, the age of the subsurface hardground crusts from $117 \mathrm{~m}$ depth in the core of Site 1194 on the NMP can be determined using beryllium isotopes. Under the assumption of a constant flux of ${ }^{10} \mathrm{Be}$ into the ocean, a constant initial ${ }^{10} \mathrm{Be} /{ }^{9} \mathrm{Be}$ ratio at the surface of the crusts, and the identical ${ }^{10} \mathrm{Be} /{ }^{9} \mathrm{Be}$ ratios $\left(0.023 \pm 0.005 \times 10^{-7}\right)$ of the two subsurface crust samples (from Section 194-1194A-14X-1), we calculate an age of $8.65 \pm 0.50$ Ma. This is in very good accordance with the biostratigraphic and seismic stratigraphic age of the hiatus (Fig. F7) during which the crust grew (7.7-11.8 Ma) (Isern, Anselmetti, Blum, et al., 2002). This hardground crust and the surface crust samples measured so far clearly do not represent the entire periods of the inferred hiatuses but only relatively brief periods within the hiatuses. The reason for these interruptions of growth are not clear, but these crusts can obviously not contribute to determine the durations of the hiatuses.
T2. Measured Be concentrations, p. 21.

F6. Beryllium plots, p. 14.

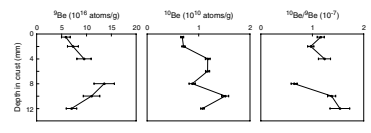

F7. Seismic profile through the NMP, p. 15.

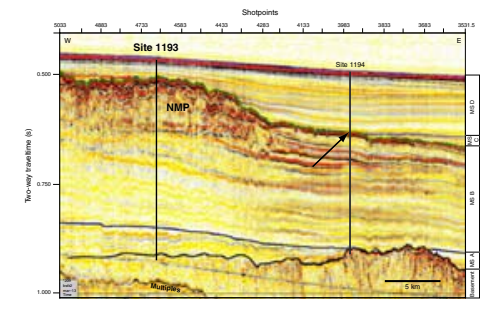




\section{Nd Isotopes}

The Nd isotope composition of all samples measured ranges between -2.7 and $0.15 \varepsilon_{\mathrm{Nd}}$. The two profiles (Fig. F8) show internally consistent trends from identical surface $\varepsilon_{\mathrm{Nd}}$ values around -2.5 toward more radiogenic $\varepsilon_{\mathrm{Nd}}$ values of up to 0 at the base of the hardground. No other $\mathrm{Nd}$ isotope data were available from the water column or from shallow ferromanganese crusts from the Tasman Sea or Coral Sea with which our data can be directly compared. They are, however, at the higher end but within the range of upper water column Nd isotope compositions measured at other locations in the central and South Pacific Ocean (Piepgras and Jacobsen, 1988; Lacan and Jeandel, 2001). They therefore confirm the hydrogenetic, seawater-derived origin of the trace metals in these hardground crusts. The surface values of the two profiles are also within error identical to the surface values of a hydrogenetic crust from $1500 \mathrm{~m}$ water depth on the Lord Howe Rise farther south in the Tasman Basin (van de Flierdt et al., 2004). The pronounced increase of $2.5 \varepsilon_{N d}$ units over the short growth period represented by the hardground indicates a significant change in the composition of the ambient deep water at the location of the SMP. This variation may be related to a glacialinterglacial change in the prevailing surface current on the SMP or, less likely, to changes in the isotopic composition of the current itself, potentially caused by changes in weathering intensity in its source region. With the currently available data in the area, this cannot be further constrained. As discussed below, it may also be possible that the pattern is a consequence of diagenetic remobilization.

\section{Genetic Classification of Hardground Crusts and Implications for Growth Conditions}

The major element composition of the hardground crusts was measured on the same aliquots used for $\mathrm{Nd}$ and Be isotope analyses in order to evaluate their hydrogenetic origin. Concentrations of the minor and trace metals $(\mathrm{Co}, \mathrm{Cu}, \mathrm{Nd}$, and $\mathrm{Pb})$ are about a factor of 50 lower than normally observed in deepwater ferromanganese crusts, whereas Be concentrations are only about a factor of 10 lower. This is consistent with the inferred high growth rates, but it may also be that metal supplies did not only originate from the water column. Mn/Fe ratios in all samples except the Mn-rich profile are between 0.001 and 0.2 , which is far below typical hydrogenetic ratios, whereas ratios for the Mn-rich layer are between 1.3 and 5.5. This is comparable to hydrogenetic ratios (Frank et al., 1999), although a value of 5 already points to diagenetic addition of $\mathrm{Mn}$. The origin of ferromanganese crusts can be further evaluated by plotting the abundances of $\mathrm{Fe}, \mathrm{Mn}, \mathrm{Co}, \mathrm{Ni}$, and $\mathrm{Cu}$ (Table T3) in a ternary diagram (Bonatti et al., 1972) (Fig. F9). Although this tool to distinguish between hydrogenetic, hydrothermal, and diagenetic origin can strictly only be applied to mixed-type ferromanganese nodules, it can provide first-order information. Only data for the Mnrich profile plot near the field of hydrogenetic growth, although some of them already plot to the right of it, which is consistent with a diagenetic addition of $\mathrm{Mn}$. All other samples plot in the lower left corner of the diagram, reflecting very high relative Fe concentrations. Given that hydrothermal additions at this location can be excluded, we argue that trace metals and Mn were mobilized out of the hardgrounds to different extents. This is most clearly visible in the subsurface hardground,
F8. $\varepsilon_{\text {Nd }}$ profile, p. 16.

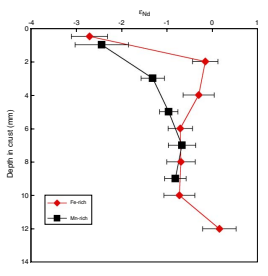

T3. Elemental concentrations, p. 22.

F9. Abundance of $\mathrm{Fe}, \mathrm{Mn}, \mathrm{Co}, \mathrm{Ni}$, and $\mathrm{Cu}, \mathrm{p} .17$.

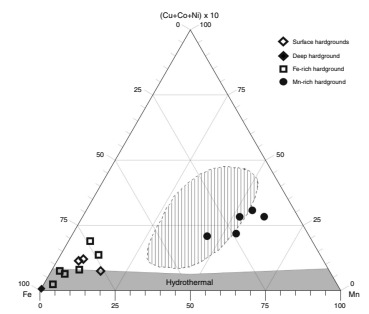


which has essentially lost all $\mathrm{Mn}, \mathrm{Co}, \mathrm{Ni}$, and $\mathrm{Cu}$, whereas more particle-reactive metals, such as $\mathrm{Be}, \mathrm{Nd}$, and $\mathrm{Pb}$, have almost completely remained in place. The Mn-rich hardground has the highest trace metal concentrations, suggesting that it is least altered by diagenesis. Its largely very low Be concentrations, below the detection limit, and the evidence from Figure F10, however, suggest that some kind of diagenesis occurred here as well.

Supporting evidence for diagenetic alteration comes from a comparison of elemental maps (Fig. F10) with thin section images (Fig. F4) that show that the reddish brown laminae are iron rich and the black opaque sections are rich in manganese. A very thin, sharp fracture separates the compositional change from Fe rich to Mn rich (Figs. F4, F10). Most of the primary growth structures can be traced across this change. This confirms the postdepositional diagenetic alteration of the Fe-rich layers by Mn loss but does not exclude that the Mn-rich layers were also diagenetically altered.

Despite the fact that $\mathrm{Be}$ and $\mathrm{Nd}$ isotope data are consistent with seawater origin, it cannot be excluded that Be and Nd have also been redistributed during the process of diagenesis, most likely on very small spatial scales, which may explain the missing decrease of the ${ }^{10} \mathrm{Be} /{ }^{9} \mathrm{Be}$ ratios with depth in the two profiles and may also be the cause for the trend in the two Nd isotope profiles.

Until now the elevated topography of the SMP, combined with the strong bottom currents, prevented particle sedimentation on top of the SMP, resulting in absent sedimentation since the late Miocene-early Pliocene. This environment allowed ferromanganese crusts to grow, as shown on seafloor photographs (Fig. F11) taken during the site survey cruise onboard the Franklin (AGSO 209; CSIRO FR 03/99) (Heck et al., 1999).

Unlike the SMP, carbonate production on the NMP never reinitiated after subaerial exposure of the late middle Miocene sea level fall. During this lowstand, a small carbonate platform grew on the upper slope of the exposed NMP. This lowstand platform eventually drowned, as did the entire NMP, when sea level rose again and flooded these platforms. Because strong currents swept the seafloor, sedimentation started much later and the slope platform became finally buried under drift deposits in the late Pliocene. Thus, similar to the SMP, the NMP has been an ideal location for formation of ferromanganese crusts because sedimentation was prevented for an extended period of time.

\section{CONCLUSIONS AND SUMMARY}

Analyses of Be and $\mathrm{Nd}$ isotopes confirm that the hardgrounds drilled and dredged at the seafloor at Site 1196 as well as the subsurface hardground at Site 1194 are ferromanganese crusts that have incorporated the trace metal isotope composition of ambient seawater. The strong currents that have swept the Marion Plateau and that have prevented sedimentation and caused large hiatuses in the sedimentary sequence were the prerequisite that these crusts formed by precipitation from seawater. Major and minor element compositions suggest diagentic alteration on small spatial scales while preserving primary growth structures. Dating attempts with Be isotopes suggest that surface hardgrounds have grown rapidly within the most recent few 100 k.y. Given that sedimentation probably stopped in early Pliocene time, this implies that hardground crust formation only started after the SMP top
F10. Electron microprobe elemental maps, p. 18.

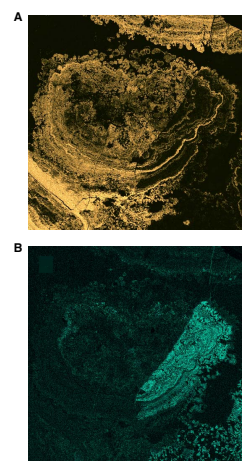

F11. Seafloor photograph of hardground, p. 19.

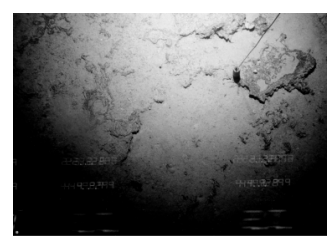


P.R. HECK ET AL.

Submarine Ferromanganese HardgroundS

7

had already been exposed to the seafloor for a few million years. The age of $8.7 \pm 0.5 \mathrm{Ma}$ obtained by Be isotope dating for the deep hardground crust at $117 \mathrm{~m}$ subsurface depth at Site 1194 is in excellent accordance with biostratigraphic and seismic stratigraphic age assignment of the hiatus (7.7-11.8 Ma) during which the crust formed.

Our results suggest that hardground crusts have been diagenetically altered but may have nevertheless preserved the initial seawater-derived Be and Nd isotope composition. The hardgrounds represent relatively fast growing Fe-Mn precipitates that only cover short periods of time during long sedimentary hiatuses and are therefore unsuitable to determine the durations of the hiatuses.

ACKNOWLEDGMENTS

The site survey cruise was funded by the Australian Geological Survery Organization (AGSO) with chief scientist Alexandra Isern. This research used samples provided by the Ocean Drilling Program (ODP). ODP is sponsored by the U.S. National Science Foundation (NSF) and participating countries under management of Joint Oceanographic Institutions (JOI), Inc. We would like to thank Roger Rütti for help with electron microprobe analyses, Tina van de Flierdt for AMS analysis, Heinz Furrer for helpful discussions, and Frowin Pirovino for preparing the thin sections. 


\section{REFERENCES}

Bonatti, E., Kraemer, T., and Rydell, H., 1972. Classification and genesis of submarine iron-manganese deposits. In Horn, D.R. (Ed.), Papers from a Conference on Ferromanganese Deposits on the Ocean Floor: Washington (Natl. Sci. Found.), 149-166.

Cohen, A.S., O'Nions, R.K., Siegenthaler, R., and Griffin, W.L., 1988. Chronology of the pressure-temperature history recorded by a granulite terrain. Contrib. Mineral. Petrol., 98(3):303-311. doi:10.1007/BF00375181

Frank, M., 2002. Radiogenic isotopes: tracers of past ocean circulation and erosional input. Rev. Geophys., 40(1):1001. doi:10.1029/2000RG000094

Frank, M., O'Nions, R.K., Hein, J.R., and Banakar, V.K., 1999. 60 Myr records of major elements and $\mathrm{Pb}-\mathrm{Nd}$ isotopes from hydrogenous ferromanganese crusts: reconstruction of seawater paleochemistry. Geochim. Cosmochim. Acta, 63(11-12):16891708. doi:10.1016/S0016-7037(99)00079-4

Heck, P.R., Anselmetti, F.S., Isern, A.R., and Stone, D., 1999. Current-controlled carbonate sedimentation on a modern platform slope: variations in sediment composition diagenetic alterations and physical properties at planned ODP Leg 194 drill sites (Marion Plateau). Eos, Trans. Am. Geophys. Union, 80(Suppl.):F525. (Abstract)

Henken-Mellies, W.U., Beer, J., Heller, F., Hsü, K.J., Shen, C., Bonani, G., Hofmann, H.J., Suter, M., and Wölfli, W., 1990. ${ }^{10}$ Be and ${ }^{9}$ Be in South Atlantic DSDP Site 519: relation to geomagnetic reversals and to sediment composition. Earth Planet. Sci. Lett., 98(3-4):267-276. doi:10.1016/0012-821X(90)90029-W

Hlawatsch, S., Garbe-Schönberg, C.D., Lechtenberg, F., Manceau, A., Tamura N., Kulik, D.A., and Kersten, M., 2002. Trace metal fluxes to ferromanganese nodules from the western Baltic Sea as a record for long-term environmental changes. Chem. Geol., 182(2-4):697-709. doi:10.1016/S0009-2541(01)00346-1

Isern, A.R., Anselmetti, F.S., and Blum, P. 2004. A Neogene carbonate platform, slope and shelf edifice shaped by sea level and ocean currents, Marion Plateau (Northeast Australia). In Eberli, G.P., Masaferro, J.L., and Sarg, J.F. (Eds.), Seismic Imaging of Carbonate Reservoirs and Systems. AAPG Mem., 81:291-307.

Isern, A.R., Anselmetti, F.S., Blum, P., et al., 2002. Proc. ODP, Init. Repts., 194: College Station, TX (Ocean Drilling Program). doi:10.2973/odp.proc.ir.194.2002

Kusakabe, M., Ku, T.L., Southon, J.R., Vogel, J.S., Nelson, D.E., Measures, C.I., and Nozaki, Y., 1987. Distribution of ${ }^{10} \mathrm{Be}$ and ${ }^{9} \mathrm{Be}$ in the Pacific Ocean. Earth Planet. Sci. Lett., 82(3-4):231-240. doi:10.1016/0012-821X(87)90198-1

Lacan, F., and Jeandel, C., 2001. Tracing Papua New Guinea imprint on the central equatorial Pacific Ocean using neodymium isotopic compositions and rare earth element patterns. Earth Planet. Sci. Lett., 186(3-4):497-512. doi:10.1016/ S0012-821X(01)00263-1

Piepgras, D.J., and Jacobsen, S.B., 1988. The isotopic composition of neodymium in the North Pacific. Geochim. Cosmochim. Acta, 52(6):1373-1381. doi:10.1016/ 0016-7037(88)90208-6

van de Flierdt, T., Frank, M., Halliday, A.N., Hein, J.R., Hattendorf, B., Günther, D., and Kubik, P.W., 2004. Deep and bottom water export from the Southern Ocean to the Pacific over the past 38 million years. Paleoceanography, 19(1):PA1020. doi:10.1029/2003PA000923

von Blanckenburg, F., O’Nions, R.K., Belshaw, N.S., Gibb, A., and Hein, J.R., 1996. Global distribution of beryllium isotopes in deep ocean water as derived from FeMn crusts. Earth Planet. Sci. Lett., 141(1-4):213-226. doi:10.1016/ 0012-821X(96)00059-3 
P.R. HECK ET AL.

SUbMARINE FERromANGANESE HARDgroundS

Figure F1. Map showing the Queensland Plateau and the Marion Plateau with sampling sites of Leg 194 and the Leg 194 site survey (solid squares), exclusively Leg 194 (red circles) and Leg 133 (open circles).

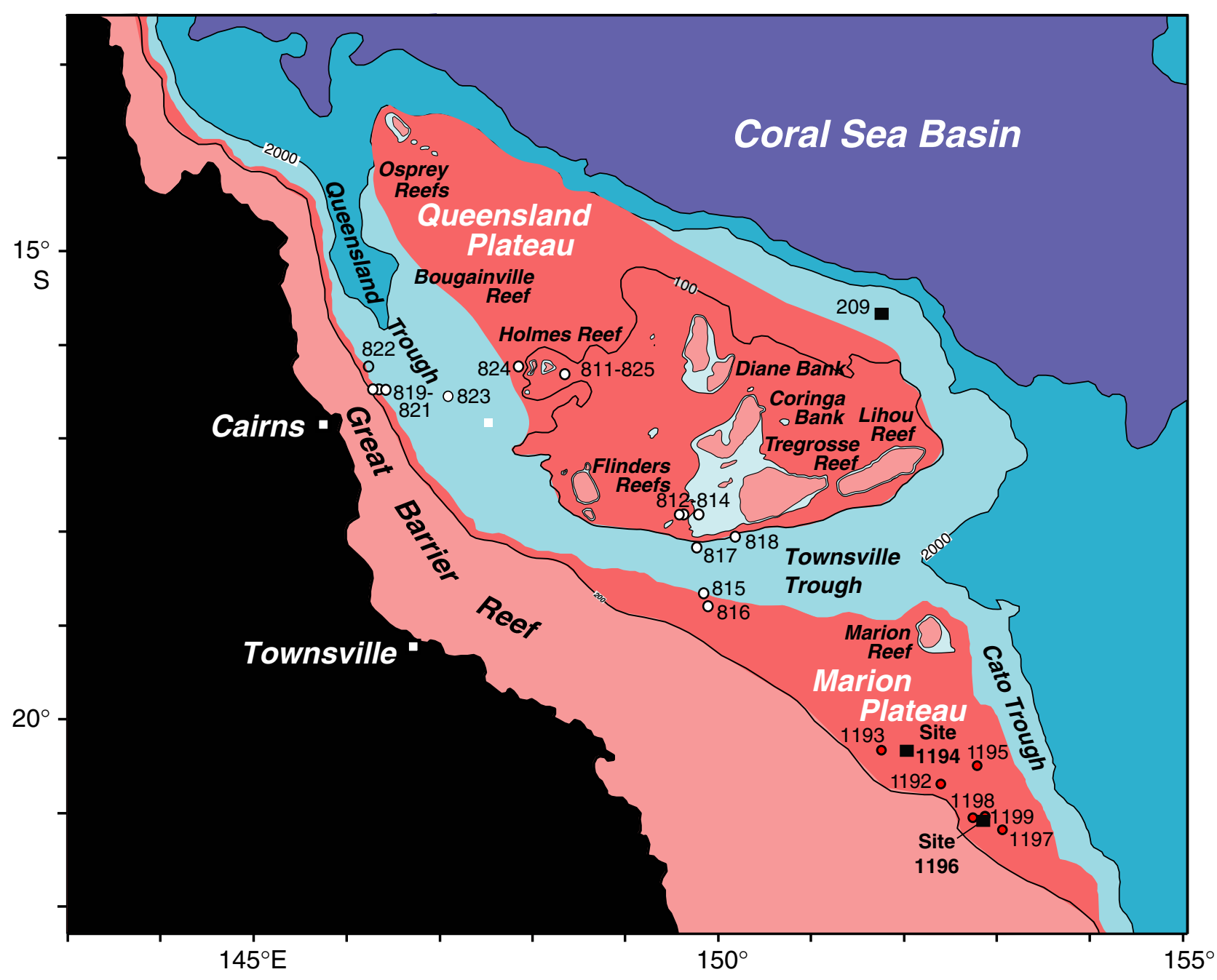


Figure F2. Seismic profile through the SMP showing locations of dredged and drilled surface crusts (Site 1194, CS-06) (Isern, Anselmetti, and Blum, et al., 2002).

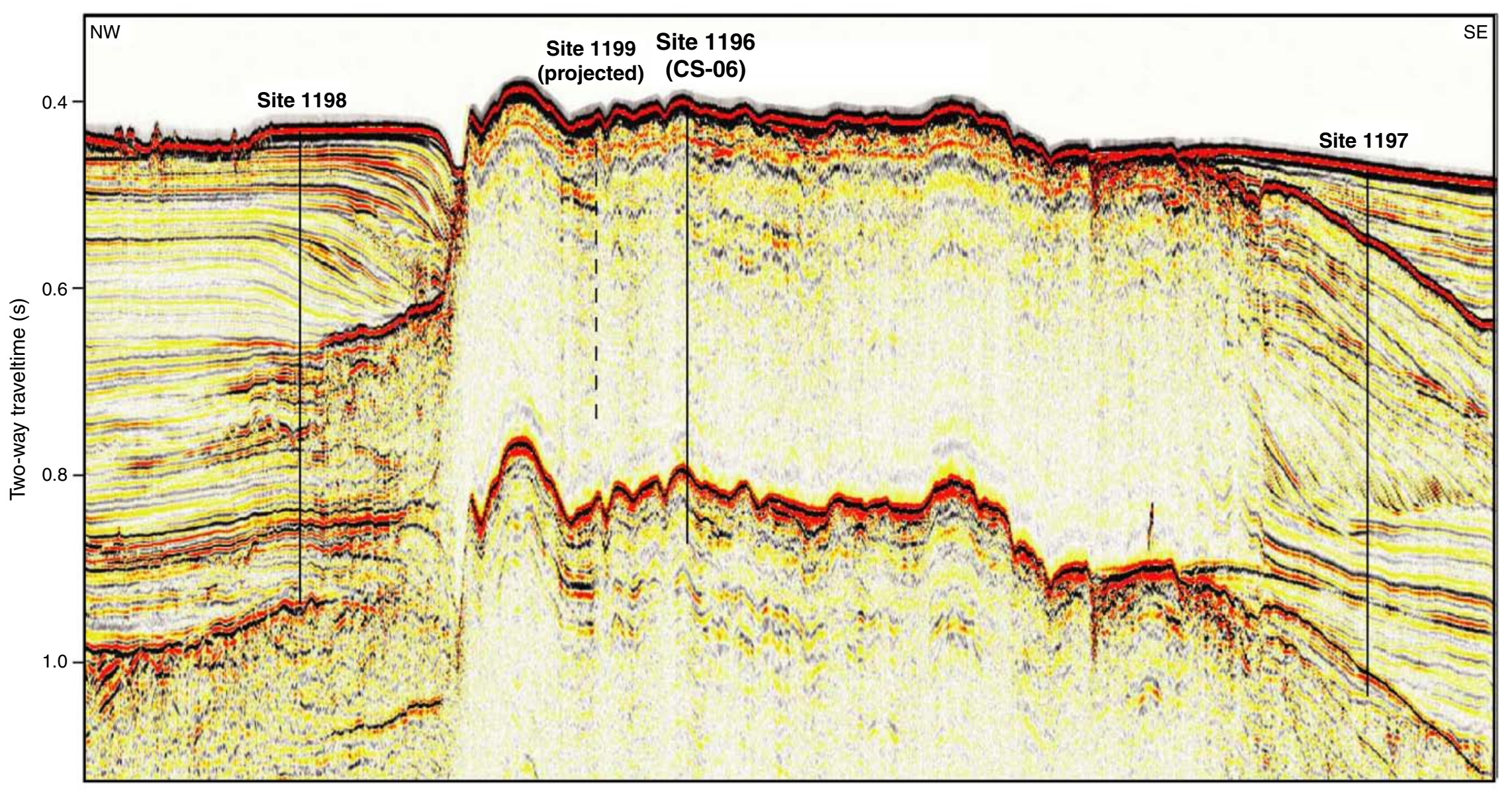


P.R. HECK ET AL.

Submarine Ferromanganese Hardgrounds

Figure F3. Dredged ferromanganese crust from Site 1196. Photo shows 2- to 3-cm-thick reddened crust colonized by bryozoans and serpulids (Heck et al., 1999).

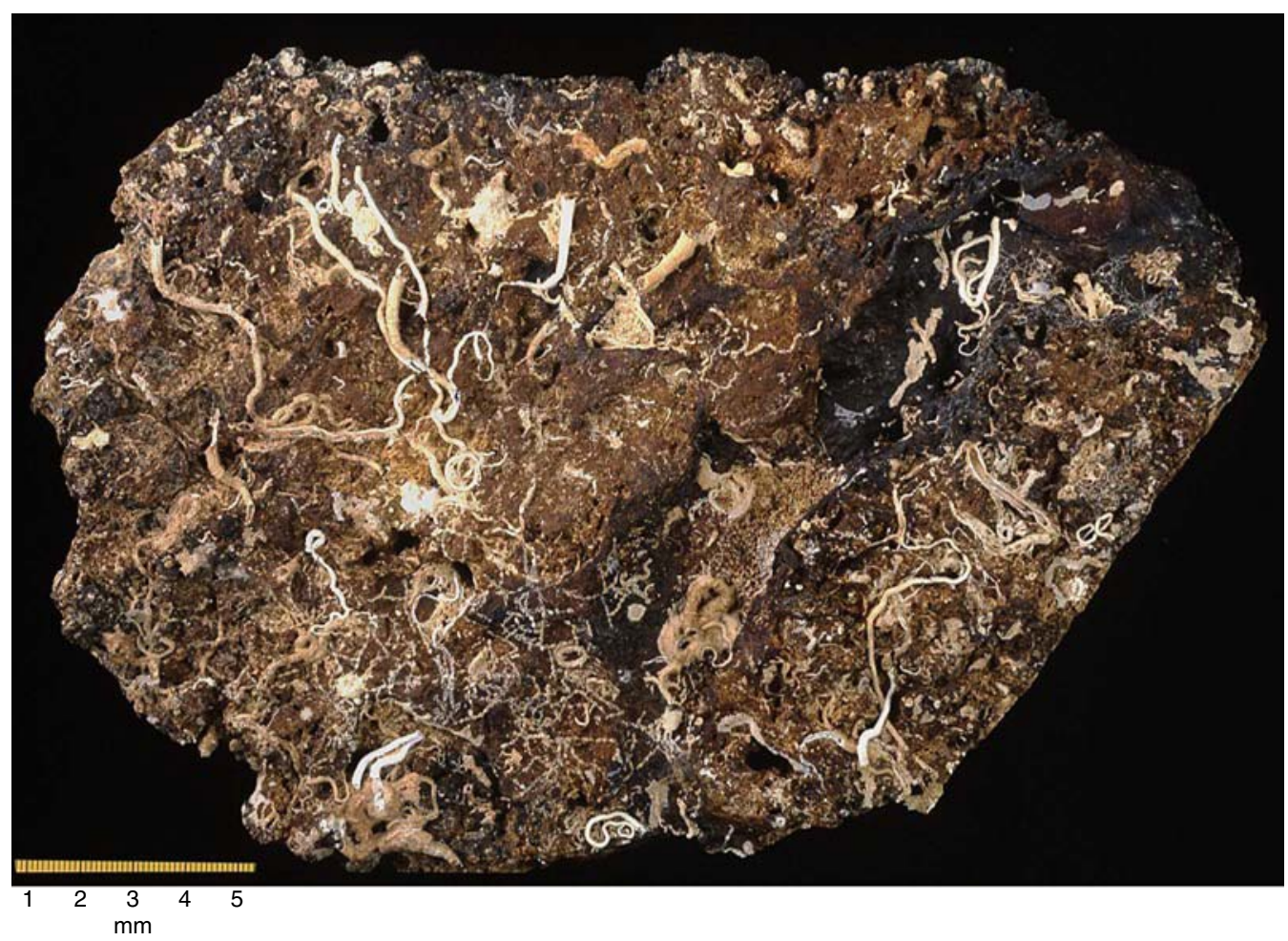


P.R. HECK ET AL.

SUbMARINE FERromANGANESE HARDgroundS

Figure F4. Optical microscope view of thin section from surface hardground Core 194-1196B-1R. The lower part consists of a floatstone with abundant foraminifers and various macrofossils. Stromatolithic crust characterizes the upper part. Note abrupt color change to opaque black in upper right. Box shows area analyzed by electron microprobe (Fig. F11, p. 19).

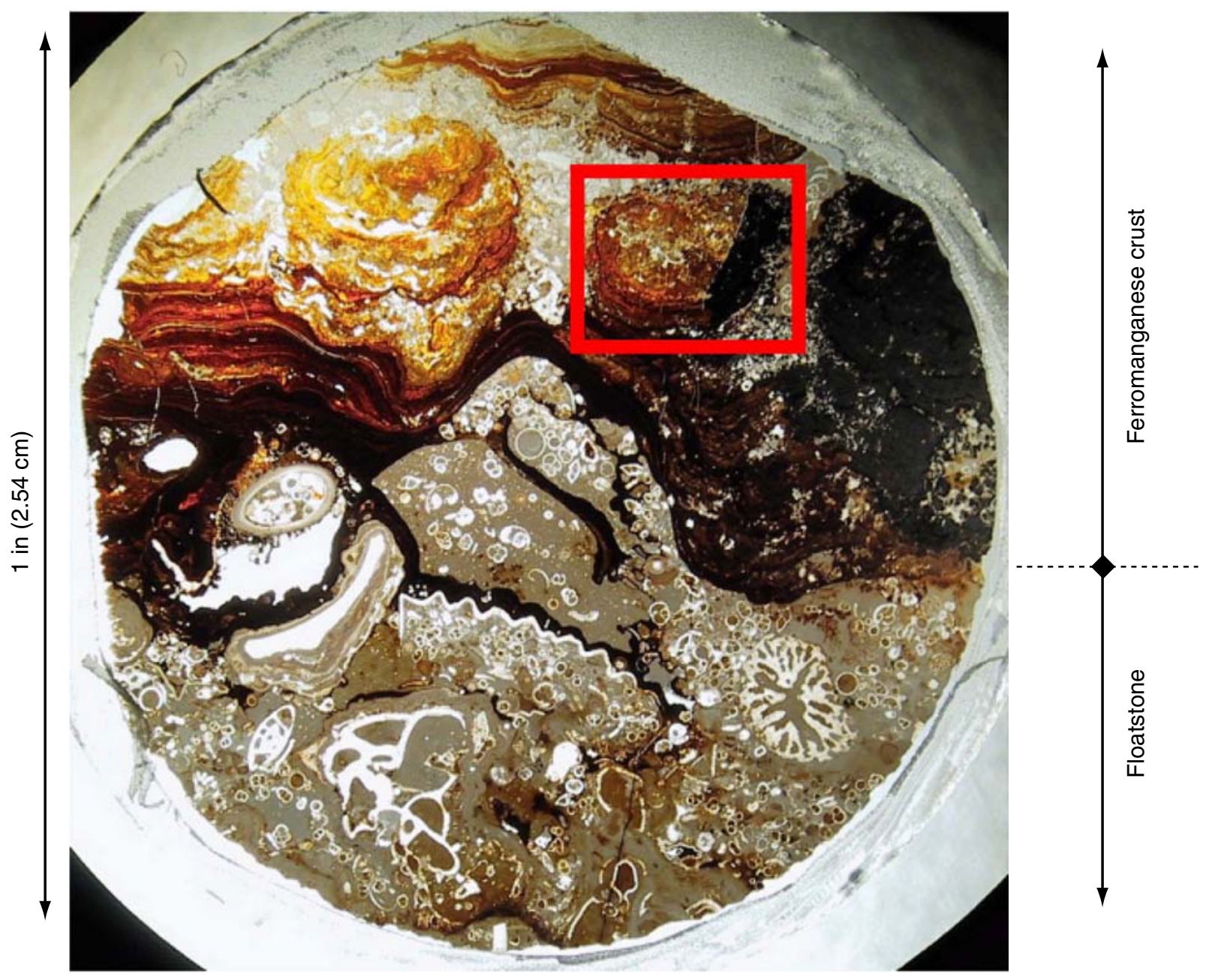


P.R. HECK ET AL.

SUbMARINE FERROMANGANESE HARDgroundS

Figure F5. Location of the subsurface crust Section 194-1194A-14X-1 (right) in the downhole natural gamma ray $\log (\mathrm{left})$.

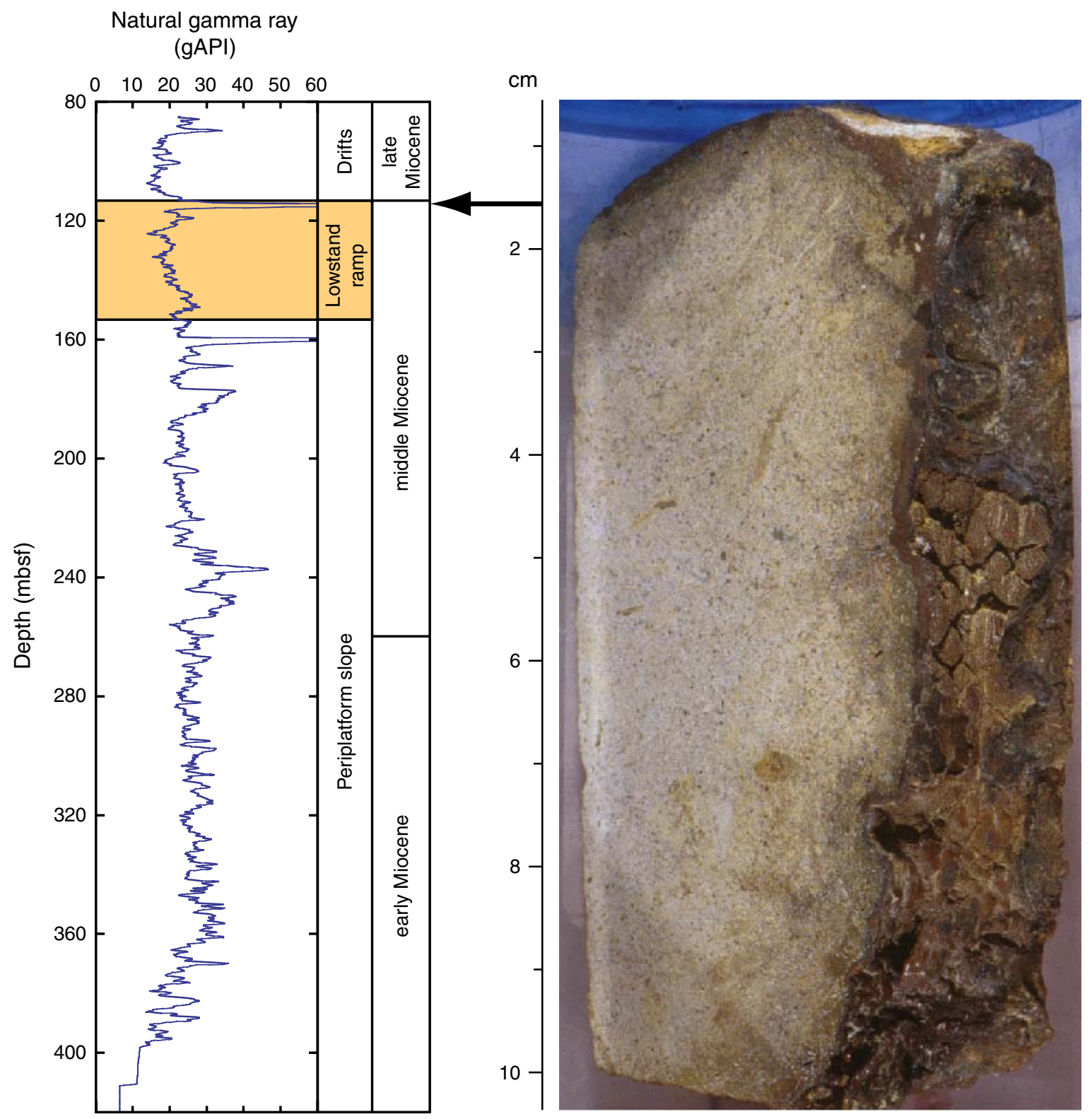


P.R. HECK ET AL.

SUbMARINE FERROMANGANESE HARDgroundS

Figure F6. Beryllium plots for profile through the Fe-rich stromatolithic part of Core 194-1196B-1R. There is no downward decrease in ${ }^{10} \mathrm{Be} .{ }^{10} \mathrm{Be} /{ }^{9} \mathrm{Be}$ averages 2 . Error bars are $1 \sigma$.
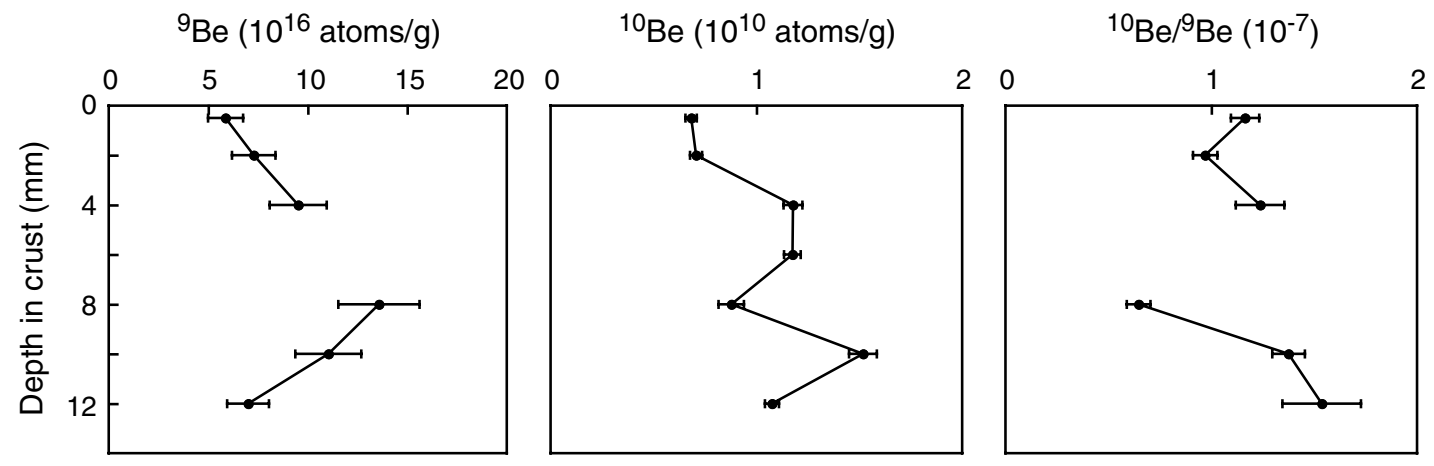
Figure F7. Seismic profile through the NMP and slope sediments. Location of drilled subsurface crust Section 194-1194A-14X-1 is indicated by arrow (Isern, Anselmetti, and Blum, et al. 2002).

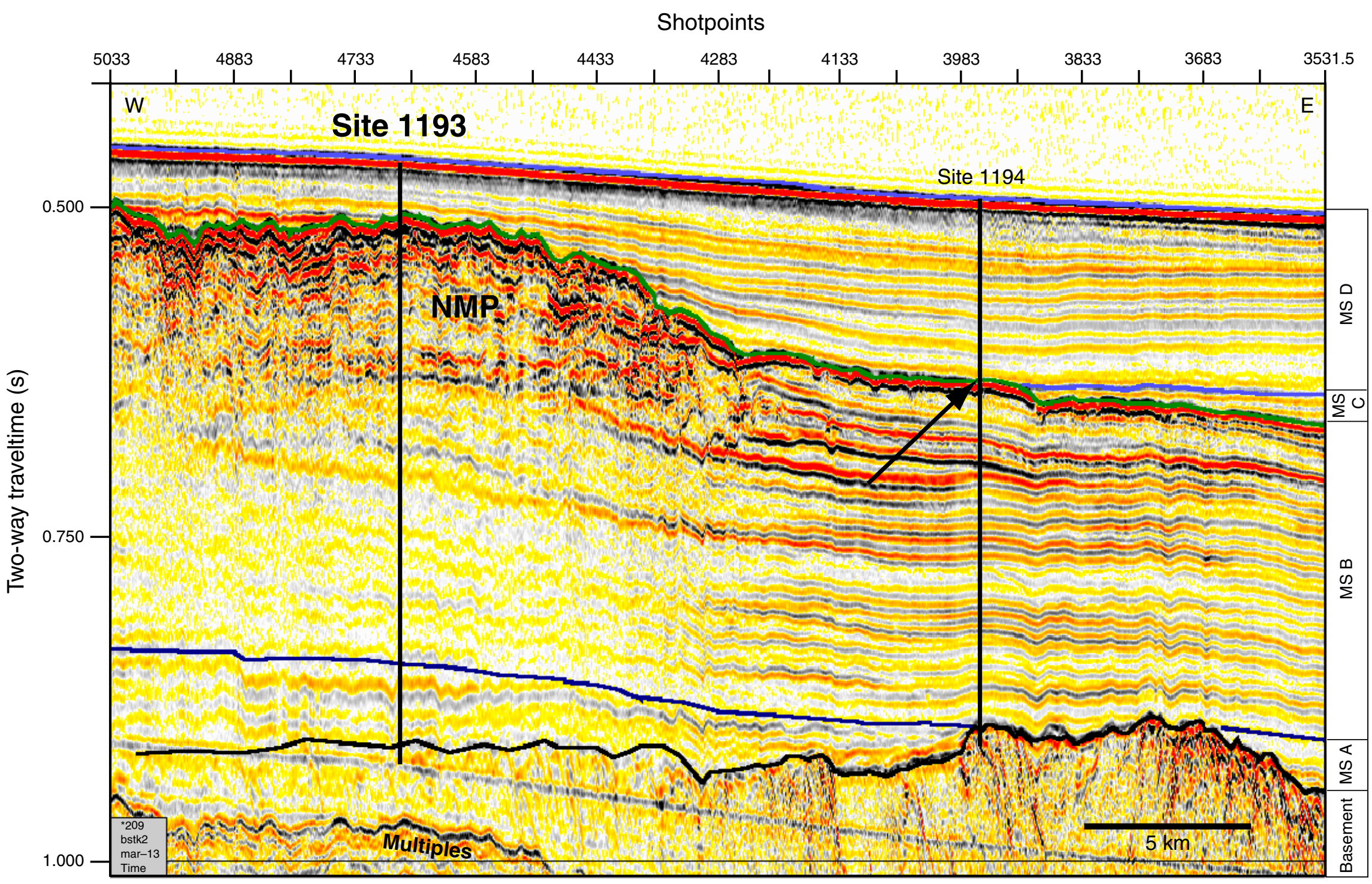


P.R. HECK ET AL.

SUbMARINE FERROMANGANESE HARDgroundS

Figure F8. $\varepsilon_{\text {Nd }}$ profile through the Fe-rich and Mn-rich stromatolithic part of Core 194-1196B-1R. Note the variation of $\varepsilon_{\mathrm{Nd}}$ over $\sim 3 \varepsilon$-units. Error bars are $1 \sigma$.

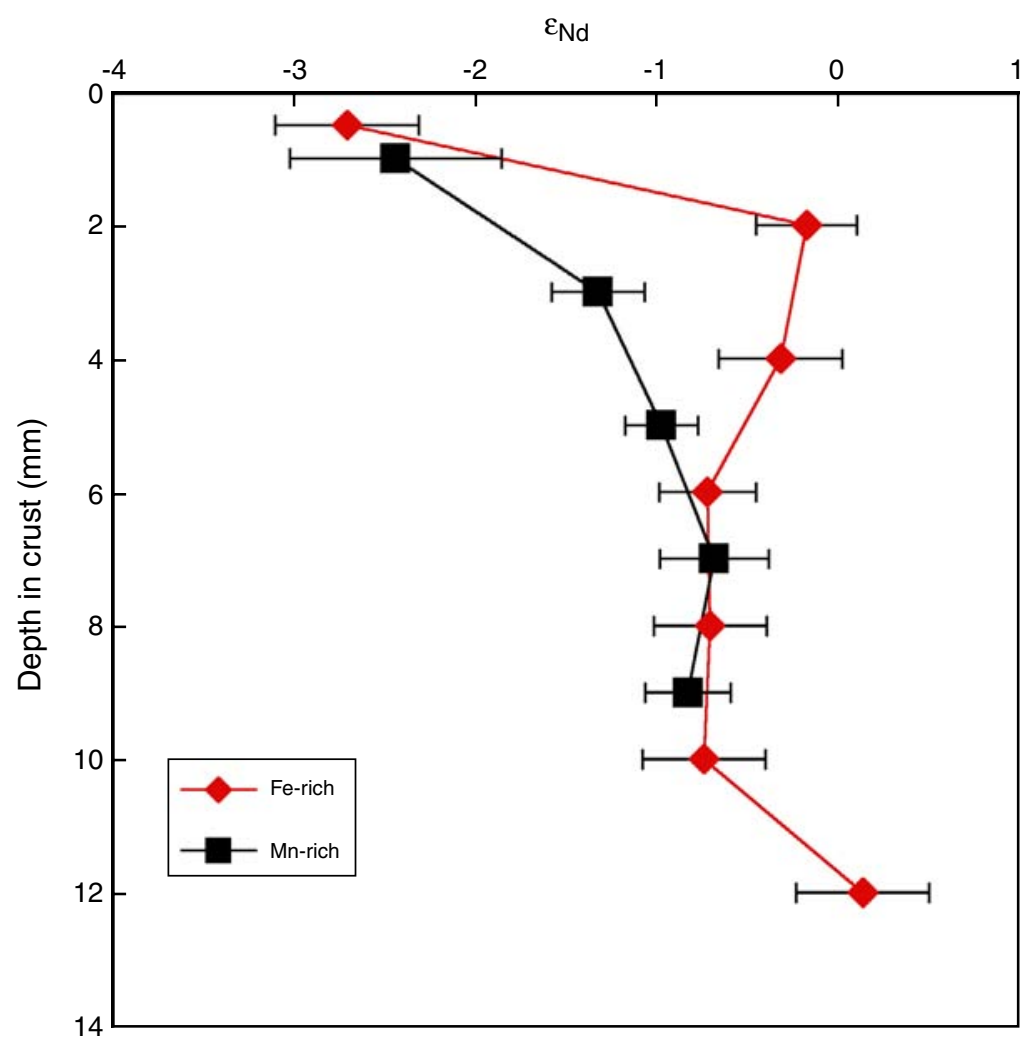


P.R. HECK ET AL.

SUBMARINE FERROMANGANESE HARDgroundS

Figure F9. Ternary diagram showing the abundances of $\mathrm{Fe}, \mathrm{Mn}, \mathrm{Co}, \mathrm{Ni}$, and $\mathrm{Cu}$ in different samples. Field of hydrogenetic growth is striped vertically; field of hydrothermal origin is shaded gray.

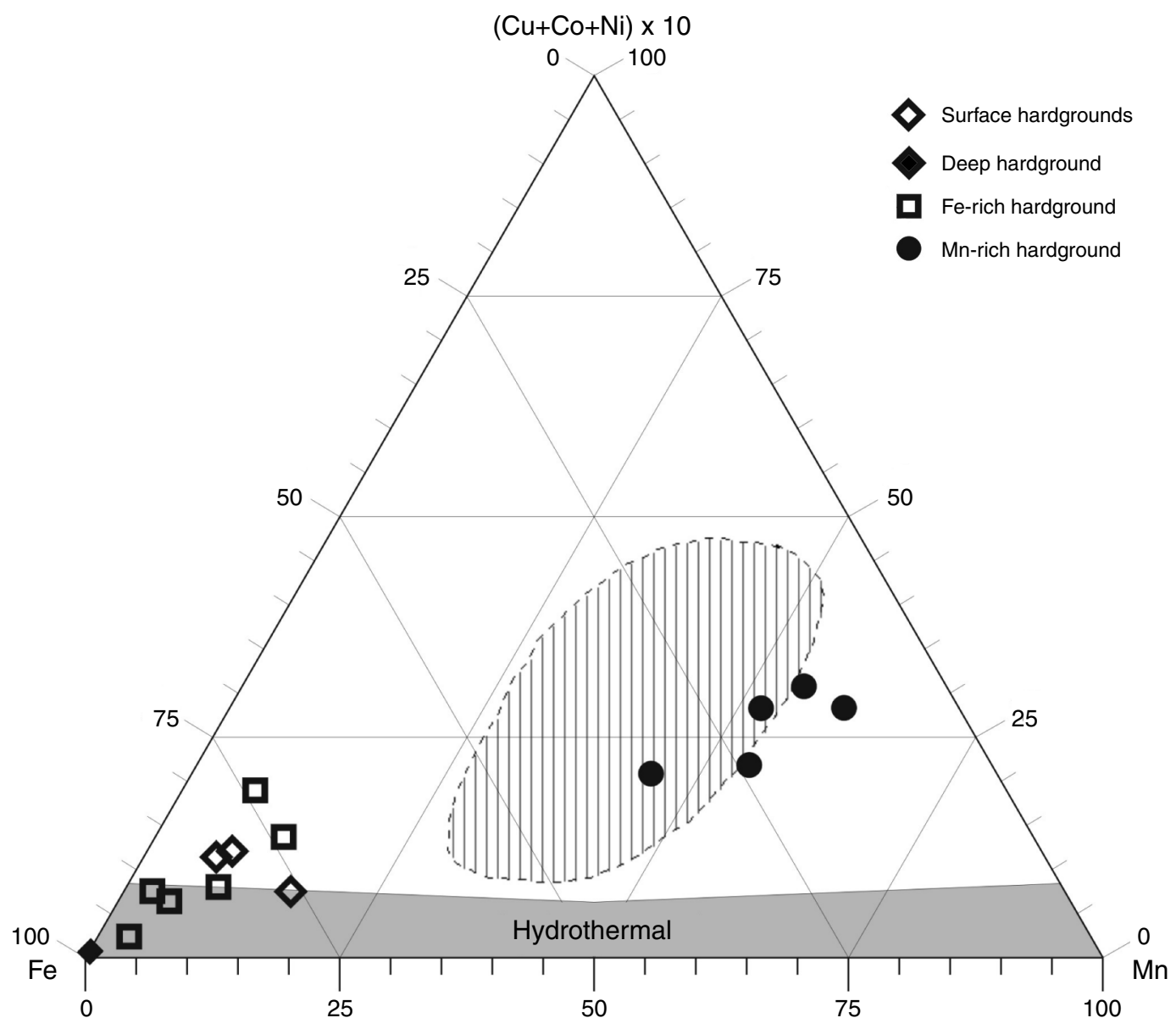


P.R. HECK ET AL.

Submarine Ferromanganese Hardgrounds

Figure F10. Electron microprobe elemental maps for (A) Fe and (B) Mn in Core 194-1196B-1R. Brightness corresponds to Fe and Mn content, respectively. Images are $0.56 \mathrm{~cm}$ across.
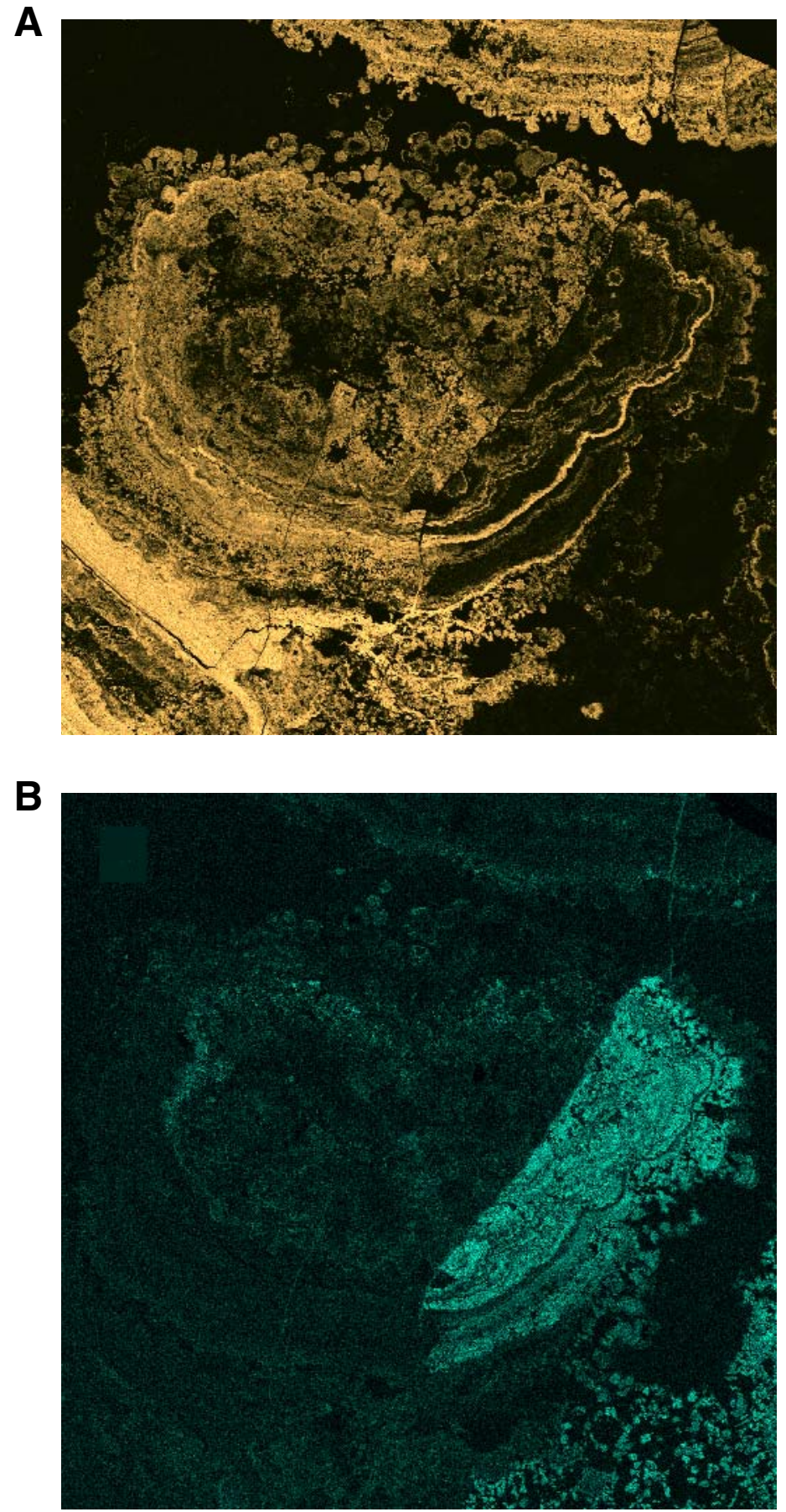
P.R. HECK ET AL.

Submarine Ferromanganese HARdgrounds

Figure F11. Seafloor photograph near Site 1196 at 304 meters below sea level, showing patchy distribution of the hardground crust on the drowned southern platform top (Heck et al., 1999).

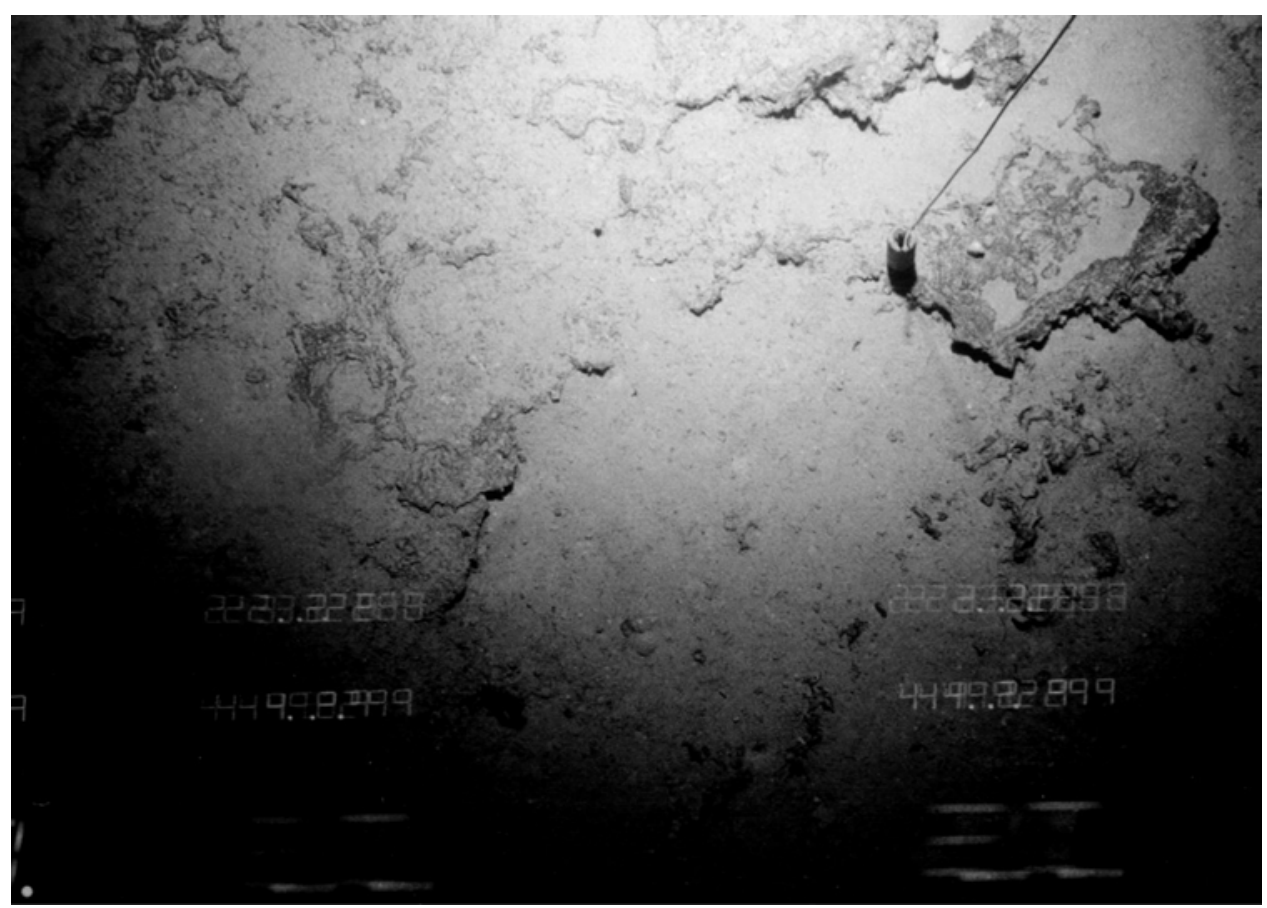


P.R. HECK ET AL.

SUBMARINE FERROMANGANESE HARDgroundS

Table T1. Sample locations of dredged and drilled surface and subsurface crusts.

\begin{tabular}{lllll}
\hline \multicolumn{1}{c}{ Site/Hole } & Water depth & GPS position & \multicolumn{1}{c}{ Sample ID } & \multicolumn{1}{c}{ Remarks } \\
\hline CS-06/1196 & $301 \mathrm{mbsl}$ & $21^{\circ} 00.564^{\prime} \mathrm{S}, 152^{\circ} 51.426^{\prime} \mathrm{E}$ & $1196-\mathrm{DR}-02$ & Surface crust on top of SMP \\
CS-06/1196 & $299 \mathrm{mbsl}$ & $21^{\circ} 00.473^{\prime} \mathrm{S}, 152^{\circ} 51.379^{\prime} \mathrm{E}$ & $1196-\mathrm{DR}-04$ & Surface crust on top of SMP \\
$1196 \mathrm{~B}$ & $\sim 300 \mathrm{mbsl}$ & & $194-1196 \mathrm{~B}-1 \mathrm{R}$ & Surface crust on top of SMP \\
$1194 \mathrm{~A}$ & $117.4 \mathrm{mbsf}$ & & $194-1194 \mathrm{~A}-14 \mathrm{X}-1$ & Subsurface crust in NMP slope \\
\hline
\end{tabular}

Note: $\mathrm{mbsl}=$ meters below sea level, $\mathrm{mbsf}=$ meters below seafloor. GPS $=$ Global Positioning System . $\mathrm{SMP}=$ Southern Marion Platform, NMP = Northern Marion Platform. 
P.R. HECK ET AL.

Submarine Ferromanganese Hardgrounds

Table T2. Measured Be concentrations.

\begin{tabular}{|c|c|c|c|c|c|c|}
\hline Sample/Subsample ID & $\begin{array}{l}\text { Average depth } \\
\quad(\mathrm{mm})\end{array}$ & ${ }^{10} \mathrm{Be}\left(10^{10} \mathrm{at} / \mathrm{g}\right)$ & ${ }^{9} \mathrm{Be}\left(10^{16} \mathrm{at} / \mathrm{g}\right)$ & ${ }^{10} \mathrm{Be} /{ }^{9} \mathrm{Be}\left(10^{-7}\right)$ & ${ }^{143} \mathrm{Nd} /{ }^{144} \mathrm{Nd} \pm 1 \sigma$ & $\varepsilon_{N d} \pm 2 \sigma$ \\
\hline \multicolumn{7}{|c|}{ Seafloor surface crust (1196-DR-02) } \\
\hline Fk640 & 0.5 & $0.923 \pm 0.023$ & $7.49 \pm 1.12$ & $1.233 \pm 0.084$ & $0.512600 \pm 3$ & $-0.74 \pm 0.40$ \\
\hline \multicolumn{7}{|c|}{ Seafloor surface crust (1196-DR-04) } \\
\hline Fk609 & 0.5 & $0.0973 \pm 0.0042$ & & & $0.512602 \pm 10$ & $-0.70 \pm 0.40$ \\
\hline Fk610 & 15 & $1.378 \pm 0.037$ & $12.63 \pm 1.89$ & $1.091 \pm 0.085$ & $0.512576 \pm 4$ & $-1.22 \pm 0.40$ \\
\hline \multicolumn{7}{|c|}{ Seafloor surface crust (194-1196B-1R) Fe-rich laminae } \\
\hline Fk628 & 0.5 & $0.683 \pm 0.028$ & $5.87 \pm 0.88$ & $1.164 \pm 0.069$ & $0.512521 \pm 10$ & $-2.29 \pm 0.40$ \\
\hline Fk629 & 2 & $0.707 \pm 0.029$ & $7.29 \pm 1.09$ & $0.970 \pm 0.059$ & $0.512630 \pm 7$ & $-0.16 \pm 0.40$ \\
\hline Fk630 & 4 & $1.178 \pm 0.046$ & $9.52 \pm 1.43$ & $1.237 \pm 0.118$ & $0.512622 \pm 9$ & $-0.31 \pm 0.40$ \\
\hline Fk631 & 6 & $1.175 \pm 0.040$ & & & $0.512602 \pm 7$ & $-0.71 \pm 0.40$ \\
\hline Fk632 & 8 & $0.878 \pm 0.062$ & $13.58 \pm 2.04$ & $0.647 \pm 0.057$ & $0.512602 \pm 8$ & $-0.69 \pm 0.40$ \\
\hline Fk633 & 10 & $1.518 \pm 0.068$ & $11.04 \pm 1.66$ & $1.376 \pm 0.079$ & $0.512601 \pm 9$ & $-0.73 \pm 0.40$ \\
\hline Fk634 & 12 & $1.076 \pm 0.034$ & $7.00 \pm 1.05$ & $1.537 \pm 0.191$ & $0.512646 \pm 9$ & $0.15 \pm 0.40$ \\
\hline \multicolumn{7}{|l|}{ Mn-rich laminae } \\
\hline Fk635 & 1 & $0.285 \pm 0.035$ & & & $0.512513 \pm 15$ & $-2.43 \pm 0.58$ \\
\hline Fk636 & 3 & $0.387 \pm 0.021$ & & & $0.512571 \pm 6$ & $-1.31 \pm 0.40$ \\
\hline Fk637 & 5 & $0.485 \pm 0.031$ & & & $0.512589 \pm 5$ & $-0.96 \pm 0.40$ \\
\hline Fk638 & 7 & $0.566 \pm 0.022$ & $4.97 \pm 0.75$ & & $0.512604 \pm 8$ & $-0.67 \pm 0.40$ \\
\hline Fk639 & 9 & $0.298 \pm 0.012$ & & & $0.512596 \pm 6$ & $-0.82 \pm 0.40$ \\
\hline \multicolumn{7}{|c|}{ Deep subsurface crust (194-1194A-14X-1) } \\
\hline Fk641 & 0.3 & $0.041 \pm 0.008$ & $17.61 \pm 2.64$ & $0.023 \pm 0.005$ & $0.512643 \pm 15$ & $0.10 \pm 0.58$ \\
\hline Fk642 & 0.8 & $0.0412 \pm 0.0049$ & $18.25 \pm 2.74$ & $0.023 \pm 0.003$ & $0.512613 \pm 6$ & $-0.48 \pm 0.40$ \\
\hline
\end{tabular}

Notes: All samples show comparable ${ }^{10} \mathrm{Be} /{ }^{9} \mathrm{Be}$ ratios except for the deep subsurface crust in Section 194-1194A-14X-1. Beryllium concentrations in the Mn-rich part of Core 194-1196B-1R were, with one exception, below detection limit. 
Table T3. Elemental concentrations in the ferromanganese crusts as measured by inductively coupled plasma mass spectrometry.

\begin{tabular}{|c|c|c|c|c|c|c|c|c|c|c|c|}
\hline \multirow[b]{2}{*}{ Sample/Subsample ID } & \multirow{2}{*}{$\begin{array}{l}\text { Average depth } \\
(\mathrm{mm})\end{array}$} & \multicolumn{7}{|c|}{ Major elements (wt\%) } & \multirow[b]{2}{*}{$\mathrm{Mn} / \mathrm{Fe}$} & \multicolumn{2}{|c|}{ Minor elements (ppm) } \\
\hline & & Co & $\mathrm{Ni}$ & $\mathrm{Mn}$ & $\mathrm{Fe}$ & $\mathrm{Cu}$ & $\mathrm{Fe}$ & $\mathrm{Mn}$ & & $\mathrm{Nd}$ & $\mathrm{Pb}$ \\
\hline \multicolumn{12}{|c|}{ Seafloor surface crust (1196-DR-02) } \\
\hline Fk640 & 0.5 & 0.015 & 0.147 & 1.428 & 13.527 & 0.043 & 79.53 & 8.39 & 0.11 & 15.9 & 103.1 \\
\hline \multicolumn{12}{|c|}{ Seafloor surface crust (1196-DR-04) } \\
\hline Fk609 & 0.5 & 0.003 & 0.024 & 0.176 & 2.000 & 0.001 & 81.44 & 7.16 & 0.09 & 4.0 & \\
\hline Fk610 & 15.0 & 0.037 & 0.146 & 4.099 & 18.968 & 0.004 & 76.08 & 16.44 & 0.22 & 17.5 & 210.4 \\
\hline \multicolumn{12}{|c|}{ Seafloor surface crust (194-1196B-1R) Fe-rich laminae } \\
\hline Fk628 & 0.5 & 0.036 & 0.118 & 1.799 & 16.452 & 0.005 & 82.93 & 9.07 & 0.11 & 6.2 & 84.0 \\
\hline Fk629 & 2.0 & 0.070 & 0.261 & 3.110 & 18.105 & 0.005 & 73.67 & 12.65 & 0.17 & 6.8 & 117.4 \\
\hline Fk630 & 4.0 & 0.040 & 0.177 & 0.808 & 25.972 & 0.002 & 89.65 & 2.79 & 0.03 & 5.8 & 126.8 \\
\hline Fk631 & 6.0 & & & & & & & & & & \\
\hline Fk632 & 8.0 & 0.049 & 0.306 & 1.362 & 13.958 & 0.004 & 73.83 & 7.20 & 0.10 & 9.1 & 57.6 \\
\hline Fk633 & 10.0 & 0.037 & 0.147 & 1.484 & 26.059 & 0.004 & 88.55 & 5.04 & 0.06 & 8.8 & 75.7 \\
\hline Fk634 & 12.0 & 0.016 & 0.044 & 0.794 & 24.255 & 0.002 & 94.50 & 3.09 & 0.03 & 5.1 & 67.8 \\
\hline \multicolumn{12}{|l|}{ Mn-rich laminae } \\
\hline Fk635 & 1.0 & 0.107 & 0.492 & 12.999 & 2.426 & 0.011 & 11.27 & 60.41 & 5.36 & 6.1 & 47.4 \\
\hline Fk636 & 3.0 & 0.088 & 0.511 & 10.944 & 2.769 & 0.010 & 13.98 & 55.26 & 3.95 & 7.5 & 63.1 \\
\hline Fk637 & 5.0 & 0.098 & 0.526 & 11.725 & 4.356 & 0.010 & 19.43 & 52.29 & 2.69 & 7.6 & 100.6 \\
\hline Fk638 & 7.0 & 0.121 & 0.425 & 13.788 & 6.046 & 0.009 & 23.82 & 54.33 & 2.28 & 7.0 & 82.8 \\
\hline Fk639 & 9.0 & 0.055 & 0.190 & 5.406 & 4.068 & 0.004 & 33.98 & 45.17 & 1.33 & 4.6 & 25.8 \\
\hline \multicolumn{12}{|c|}{ Deep subsurface crust (194-1194A-14X-1) } \\
\hline Fk641 & 0.3 & 0.008 & 0.024 & 0.066 & 52.940 & 0.001 & 99.27 & 0.12 & 0.0013 & 2.4 & 37.3 \\
\hline Fk642 & 0.8 & 0.009 & 0.030 & 0.084 & 52.977 & 0.000 & 99.09 & 0.16 & 0.0016 & 5.3 & 38.1 \\
\hline
\end{tabular}

